\title{
MANAJEMEN PERUBAHAN: KULINER MAKANAN TRADISIONAL UMKM DAWET DESA SANGKANHURIP KABUPATEN BANDUNG
}

\author{
Deni Hamdani \\ dnhamdani34@gmail.com \\ Hery Syaerul Homan \\ hery.syaerul@ekuitas.ac.id \\ Siska Willy \\ siska_msws@ekuitas.ac.id
}

SEKOLAH TINGGI ILMU EKONOMI EKUITAS

\begin{abstract}
ABSTRAK
Kecamatan Katapang merupakan kecamatan di Kabupaten Bandung yang memiliki beragam jenis usaha sampai dengan tingkat nasional. Usaha mikro yang menjadi perhatian kami adalah produksi kuliner tradisional dawet. Hal ini didasarkan pada penghasilan perhari asal cukup untuk makan pada hari itu dan dijadikan modal untuk berjualan besok harinya, proses pembuatan dawet yang masih tradisional dan kapasitas produksi renda namun permintaan cukup tinggi, belum mempunyai merk dagang, kemasan dan plang tempat produksi, daerah pemasaran yang terbatas berdasarkan langganan dan belum memperluas daerah pemasaran. Pengelolaan pemasaran masih dilakukan secara sederhana dengan cara menjual langsung kepada masyarakat atau ditenteng berkeliling kampong di sekitaran Desa Sangkanghurip dan Desa Sukamukti. Hal ini desebabkan karena keterbatasan pengetahuan pemilik usaha Dawet dan produk turunanya yang terdiri dari dodol moyeg, palupis, ketan goreng dan cilok tentang cara pemasaran, bagaimana mengkomunikasikan dan pembuatan laporan keuangan. Tujuan pengabdian ini adalah untuk memberi pengetahuan dasar mengenai manajemen perubahan dalam pemasaran, mengidentifikasi pasar sasaran, dan menerapkan komunikasi pemasaran yang tepat. Serta pencatatan dan pelaporan keuangan sederhana. Pengabdian yang dilakukan pada Usaha mikro ini pada akhirnya mampu menerapkan manajemen perubahan, pemasaran dengan baik dan dapat meningkatkan daerah pemasarannya serta tertib laporan keuangan.
\end{abstract}

Kata kunci: Kuliner, Makanan Tradisional, Manajemen Perubahan.

\section{PENDAHULUAN}

Kecamatan Katapang merupakan kecamatan di Kabupaten Bandung, yang terdiri dari 7 (tujuh) Desa yang meliputi Desa Sukamukti, Desa Sangkanhurip, Desa Pangauban, Desa Gandasari, Desa
Banyusari, Desa Cilampeni dan Desa Katapang.

Kecataman katapang merupakan salah satu desa yang ada di Desa Sangkanhurip. Berdasarkan informasi yang didapat dari tokoh masyarakat, Desa Sangkanhurip dahulunya adalah Desa Juntihilir yang 
terbentuk pada Tahun 1930 dan pada Tahun 1956. Kemudian Desa Juntihilir digabungkan dengan Desa Sekepeuris dan desanya diubah menjadi Desa Sukagalih Kecamatan Pameungpeuk.

Diadakan pemekaran desa dan berdasarkan rumusan panitia Pemekaran Desa Sukagalih berdasarkan Surat Keputusan Gubernur Jawa Barat Nomor 163/JPM 122/SK/76, tanggal 22 April 1976. Pemekaran desa dilakukan menjadi dua Desa, dengan nama desa masingmasing yaitu:

- Desa Sangkanhurip, dan

- Desa Sukamukti

Desa Sangkanhurip secara administrasi masuk wilayah Kecamatan Pameungpeuk dan pada Tahun 1983 dengan adanya pemekaran Kecamatan Pameungpeuk menjadi Kecamatan Pameungpeuk dan Kecamatan Katapang Desa Sangkanhurip masuk pada wilayah Kecamatan Katapang, dan saat ini Desa Sangkanhurip menjadi Ibu Kota Kecamatan Katapang.

Wilayah Desa Sangkanhurip bagian dari Kecamatan Katapang, dengan luas kawasan 306 Ha yang dibatasi oleh batas administrasi yaitu:

- Sebelah Utara : Kelurahan Sulaeman

- Sebelah Selatan : Desa Banyusari dan BojongKunci

- Sebelah Timur : Desa Sukamukti dan Bojong Kunci

- Sebelah Barat : Desa Pangauban

Diantara usaha yang ada telah berkembang terdapat usaha yang memiliki daerah pemasaran yang luas sampai tingkat nasional. Usaha tersebut adalah usaha sangkar burung, usaha kuliner makanan tradisional masih bersifat lokal. Usaha ini telah memiliki pengelolaan usaha yang baik. Dari fakta tersebut, mucul pertanyaan yaitu mengapa jenis usaha yang lain tidak dapat megikuti jejak kesuksesan usaha sangkar burung tersebut. Salah satu sebab usaha sangkar burung memilki pengelolaan usaha yang baik adalah usaha ini pernah mendapat pendidikan, pelatihan, dan pendampingan dari salah satu badan usaha milik pemerintah. Dengan demikian, pola yang sama, memberikan pendidikan, pelatihan, dan pendampingan, dapat dilakukan juga terhadap sektor atau jenis usaha lainnya.

Desa Sangkanhurip, selain memiliki kinerja LAKIP yang baik, juga termasuk kelurahan yang memiliki potensi tinggi dalam bidang usaha. Usaha di sektor produksi dan sektor jasa cukup berkembang dengan baik. Adapun usaha yang telah berkembang dalam sektor produksi antara lain:

1. Pembuatan sangkar burung

2. Peranian

3. Properti

4. Kuliner tradisonal (agrem, ketan serundeng, ketan puli, ketan goreng, ketan nasi, jalabria, cilok, cireng, surandil, Dawet, Ulen)

5. Jasa perbaikan elektronik

6. Jasa Penjahit

7. Produksi tas imitasi

8. Produksi keripik, roti dan topi

Berdasarkan informasi yang bersumber dari kepala pemerintahan tingkat Desa, kendala yang dihadapi pelaku usaha di lingkungan Desa Sangkanhurip adalah lemahnya pengadministrasian keuangan, kurang luasnya daerah pemasaran, dan kurangnya akses permodalan, sehingga pembiayaan banyak menggnakan jasa rentenir. Selain itu, pelaku usaha sebenarnya telah mendapat pelatihan dan pendampingan melalui kerja sama dengan pihak swasta, tetapi lemahnya pengawasan setelah kegiatan membuat pelaku usaha tidak mampu mengembangkan pengetahuan dan keterampilan yang telah didapatnya.

Usaha mikro yang menjadi perhatian kami adalah produksi kuliner tradisional dawet. Hal ini didasarkan pada penghasilan perhari asal cukup untuk makan pada hari itu dan dijadikan modal untuk berjualan besok harinya, proses pembuatan dawet yang masih tradisional dan kapasitas produksi renda namun permintaan cukup tinggi, belum mempunyai merk dagang, kemasan dan plang tempat produksi, daerah pemasaran yang terbatas berdasarkan 
langganan dan belum memperluas daerah pemasaran.

Pengelolaan pemasaran masih dilakukan secara sederhana dengan cara menjual langsung kepada masyarakat atau ditenteng berkeliling kampong di sekitaran Desa Sangkanghurip dan Desa Sukamukti. Hal ini desebabkan karena keterbatasan pengetahuan pemilik usaha Dawet dan produk turunanya yang terdiri dari dodol moyeg, palupis, ketan goreng dan cilok tentang cara pemasaran, mengomunikasikan dan pembuatan laporan keuangan.

Profil usaha kuliner makan tradisonal yang di kelola oleh Bapak Ujang Koswara dan Ibu Elis di Kampung Cibolerang RT 01 RW 18 berada pada kecamatan Katapang Kabupaten Bandung dan berada pada Desa Sangkanhurip. Pemilik usaha UMKM UMKM ini merupakan keluarga prasejahtera, akan tetapi memiliki potensi kewirausahaan yang cukup baik, namun dalam proses perkembangannya mengalami kendala.

\section{METODE KEGIATAN}

Tahapan kegiatan pelaksanaan Pengabdian pada Masyarakat ini terdiri dari tahap persiapan awal, tahapan pelaksanaan dan tahapan akhir dengan rincian sebagai berikut:

1. Tahapan Awal Persiapan Kegiatan Pengabdian Pada Masyarakat

1. Tim STIE Ekuitas melakukan survei dan wawancara sangsung dengan Kepala Desa Sangkanhurip Bapak Jajang.

2. Tim STIE Ekuitas melakukan survey dan wawancara dengan pelaku usaha UMKM Bapak Ujang dan Ibu Elis.

3. Tim STIE melakukan pembuatan modul Komunikasi Pemasaran untuk usaha mikro.

2. Tahapan Pelaksanaan Kegiatan Pengabdian Pada Masyarakat

Pelaksanaan Pelatihan komunikasi pemasaran untuk usaha mikro
3. Tahapan Akhir Kegiatan Pengabdian Pada Masyarakat

a. Pengawasan dan Evaluasi

Pendampingan sampai tercipta kemandirian pelaku usaha dalam menerapkan manajemen perubahan, komunikasi pemasaran dan laporan keuangan sederhana.

\section{HASIL DAN LUARAN}

\section{Tahapan Awal}

Pada tahapan awal ini kami mendapatkan beberapa hal penting, yaitu:

1. Setelah melaksanakan survey pendahuluan, tim mendapatkan gambaran Demografi wilayah Desa Sangkanhurip.

2. Paparan awal kebutuhan masyarakat desa Sangkanhurip secara umum.

3. Data persentase kelompok usaha di Desa Sangkanhurip.

4. Kebutuhan komunikasi pemasaran .

5. Modul.

II. Pelaksanaan

A. Pelaksanaan Pelatihan Pembukuan Keuangan Sederhana untuk UMKM Dawet Pelatihan pembukuan keuangan sederhana dilaksanakan pada sesi kedua dari rangkaian kegiatan pengabdian pada UMKM yang memproduksi dawet. Namun selain dawet, mitra UMKM juga memproduksi 9 produk lainnya, yaitu ali agrem, ketan serundeng, ketan puli, ketan goreng, ketan nasi, jalabria, cilok, cireng dan surandil. Materi pertama yang diberikan adalah pengenalan atau pendahuluan mengenai akuntansi. Pemateri memberikan penjelasan mengenai konsep akuntansi dan pentingnya akuntansi bagi UMKM. Peserta belum memahami konsep serta manfaat menerapkan ilmu akuntansi dalam proses pencatatan dan pelaporan keuangan usahanya, bahkan sebagian besar peserta pelatihan menganggap bahwa akuntansi adalah bidang yang rumit, susah, merepotkan, dan menghabiskan waktu. 
Materi selanjutnya membahas mengenai pentingnya akuntansi bagi usaha kecil (UMKM). Pada sesi ini terjadi diskusi yang menarik antara peserta dengan pemateri mengenai konsep dasar usaha. Salah satu asumsi dasar penerapan akuntansi adalah menerapkan pencatatan akuntansi untuk entitas ekonomi. Beberapa peserta memiliki persepsi berbeda tentang usaha atau entitas. Berdasarkan diskusi konsep entitas ini akhirnya diperoleh pemahaman mengenai konsep entitas.

Setelah diperoleh pemahaman mengenai konsep entitas, dilanjutkan dengan fungsi pelaporan keuangan bagi etitas. Pada sesi ini dijelaskan oleh pemateri mengenai jenis-jenis laporan keungan beserta fungsi dan manfaatnya. Materi dilanjutkan mengenai transaksitransaksi akuntansi UMKM. Pada sesi ini, masing-masing peserta diminta menjelaskan aktivitas operasi masingmasing usaha yang dialami sehari-hari. Selanjutnya diidentifikasi aktivitas-aktivitas ekonomi dan aktivitas nonekonomi. Berdasarkan aktivitas ekonomi yang telah diidentifikasi, selanjutnya dilakukan pencatatan akuntansi. Aktivitas yang diidentifikasi tersebut diawali dari aktivitas memulai usaha (investasi awal), transaksi pembelian perlengkapan, peralatan, bahan baku, pembelanjaan/ pengeluaran, pemasukan/penerimaan dan sejenisnya.

Peserta diminta

untuk mengidentifikasi transaksi yang diberikan oleh pemateri yang berhubungan dengan kegiatan usaha. Pencatatan transaksi yang telah dilakuan sebelumnya oleh peserta tidak ada secara tertulis. Peserta hanya membeli barang-barang keperluan pembuatan bahan makanan. Jadi peserta hanya mencatat bahan makan untuk pembuatan dawet yang terdiri dari tepung beras, gula pasir, tepung tapioka, gula merah, kelapa, dan lain-lain.

Pendapatan yang didapatkan oleh penjual juga tidak dicatat secara tertulis, sehingga diidentifikasi lagi dengan cara tanya jawab dan diskusi.
Transaksi dalam perusahaan tersebut diidentifikasi pengaruhnya terhadap perusahaan kemudian dicatat menggunakan persamaan akuntansi. Peserta dibimbing untuk mengidentifikasi transaksi tersebut kemudian masing-masing peserta mencatatnya pada modul yang telah dibagikan sebelumnya. Pada sesi ini terlihat perserta yang sangat antusias mengikuti pelatihan.

Persamaan akuntansi yang dibuat adalah:

$$
\text { Harta }=\text { Kewajiban }+ \text { Modal }
$$

Kami mengambil contoh untuk pembuatan dawet saja. Dalam 1 hari untuk dawet dibutuhkan modal sebesar Rp100.000,00 dan akan menghasilkan 30 bungkus dawet. Harga perbungkus dawet ini dijual sebesar Rp7.000,00. Sehingga jika terjual habis, penjual akan mendapatkan uang sebesar Rp210.000,00 dengan keuntungan Rp110.000,00. Jika tidak habis, maka dawet tersebut akan dimakan sendiri oleh keluarga, karena tidak bisa dijual kembali besok harinya. Dari keterangan tersebut kami dapat membuat persamaan akuntansi sebagai berikut:

Kas $=$ Hutang + Modal+Penjualan-Beban $\mathrm{Rp} 210.000,00=0+\operatorname{Rp} 100.000,00+$ Rp210.000,00 - Rp100.000,00.

Setelah seluruh transaksi pada contoh kasus dicatat pada persamaan akuntansi, materi selanjutnya adalah membuat laporan keuangan, sebagai berikut:

\section{Laporan Laba Rugi}

Pendapatan Rp210.000,00

HPP $\quad \underline{(R p 100.000,00)}$

Keuntungan Rp110.000,00

7. Neraca

Aset

Kas

Jumlah Aset $\quad \frac{\mathrm{Rp210.000,00}}{\mathrm{Rp210}}$

Kewajiban

Hutang $\quad \underline{R p 0,00}$ 
Jumlah Kewajiban Rp0,00

\begin{tabular}{ll} 
Modal & \\
Modal & Rp100.000,00 \\
Laba & Rp1 $10.000,00$ \\
\hline Jumlah Modal & Rp210.000,00
\end{tabular}

Target dari pelatihan pembukuan sederhana ini adalah peserta mampu menyusun laporan laba-rugi dan neracanya sendiri tanpa bantuan dari kami. Berdasarkan persamaan akuntansi yang telah dibuat, peserta dibimbing untuk menyusun laporan laba-rugi. Sebagian besar peserta akhirnya dapat menyusun laporan laba-rugi dan memahami sedikit tentang neracanya. Sebagian besar dari peserta juga baru memahami bahwa untuk menghitung laba-rugi yang diperhitungkan adalah total pendapatan dan total beban. Peserta juga terlihat antusias dan berharap mampu menerapkannya pada usahanya. Hal ini terlihat dari pertanyaan-pertanyaan yang disampaikan oleh para peserta.

Secara umum tujuan pelatihan dapat dikatakan tercapai. Namun, hal yang lebih penting adalah bagaimana mitra UMKM dapat menerapkannya pada usahanya. Untuk itu diperlukan pembiasaan. Pembiasaan sederhana yang perlu dilakukan adalah mencatat setiap transaksi yang terjadi pada usahanya. Oleh karena itu, kami memberikan juga pelatihan pencatatan sederhana yaitu mengenai pencatatan pengeluaran, hasil produksi, dan pemasukan. Pencatatan pengeluaran yang dimaksud adalah biaya-biaya yang dikeluarkan untuk membeli bahan baku dan kebutuhan lainnya untuk menjalankan usaha. Pada bagian hasil produksi dicatat mengenai makanan apa yang dihasilkan serta berapa jumlahnya. Sedangkan pada pencatatan pemasukan, yaitu mencatat berapa banyak setiap jenis makanan yang terjual beserta harganya.

Setelah melakukan wawancara, tim membuatkan format untuk diisi setiap harinya oleh mitra UMKM. Format ini nantinya akan memberikan informasi mengenai laporan penerimaan dan pengeluaran mitra UMKM. Selama pelatihan mitra berkomitmen untuk melaksanakannya. Bagi kami, langkah ini perlu dilakukan secara konsisten terlebih dahulu oleh mitra UMKM sebelum melanjutkan pada langkah selanjutnya. Kami berencana akan meninjau perkembangan dari kegiatan ini sekitar satu bulan ke depan.

B. Pelaksanaan Pelatihan Proses Komunikasi Pemasaran UMKM Usaha Makanan Tradisional

Materi promosi usaha makanan tradisional disampaikan pada sesi pertama, yang menyangkut materi mengenai tentang:

1. Konsep manajemen pemasaran;

2. Promosi.

Merupakan tujuan dasar dari program penjualan untuk menguntungkan perusahaan. Di dalam promosi ini perusahaan membuat strategi dan perencanaan yang ingin dicapai perusahaan kedepannya. Misalnya iklan yang merupakan teknik penjualan yang sering digunakan untuk meningkatkan volume penjualan produk barang dan jasa. Teknik penjualan ini dilakukan oleh penjual untuk mendapatkan konsumen sebanyakbanyaknya.

Tahapan-tahapan yang dibutuhkan dalam teknik penjualan ini adalah:

1) Persiapan sebelum penjualan

Menetapkan siapa yang akan menjual produk dengan memberikan informasi mengenai produk atau barang yang akan dijual, konsumen yang dituju dan teknik penjualannya.

2) Penentuan Lokasi Pembeli Potensial

Pada bagian ini menentukan dimana sasaran dari segmen yang diincar. Pada bagian ini diatur stratetgi dengan cara membuat daftar calon pembeli.

3) Pendekatan Pendahuluan

Penjual harus memahami permasalahan tentang calon pembeli dan mengetahui produk yang sedang digunakan pembeli. Informasi lain yang perlu dikumpulkan oleh penjual adalah kebiasaan, kegemaran dan kesukaan dari 
calon pembeli yang merupakan pendekatan pendahuluan terhadap calon konsumennya.

4) Melakukan Penjualan

Penjualan dilakukan dengan berbagai strategi untuk menarik calon konsumen, penjual mencari tahu mengenai keinginan dari calon konsumen dan kemudian melakukan penjualan kepada pembeli.

Penjual harus mempelajari beberapa hal sebelum melakukan penjualan yaitu permasalahan tentang calon pembeli dan mengetahui produk yang digunakan pembeli. Informasi lain juga dibutuhkan oleh penjual diantaranya adalah bagaimana sifat calon pembeli terhadap penawaran produk barunya dan kebiasaan pembeli.

Hal tersebut di atas merupakan pendekatan strategi terhadap pasar calon pembeli.

5) Pelayanan Sesudah penjualan (Purna jual)

Kegiatan penjualan tidak berakhir kepada barang dibeli oleh pembeli, akan tetapi bagaimana peningkatan kualitas setelah barang dibeli oleh pembeli. Apakah pembeli akan kembali kepada penjual untuk melakukan pembelian kembali dan service yang diberikan oleh pembeli seperti pembelin barang elektronik, kendaraan, dll.

Tahapan-tahapan setelah penjualan barang dagang kepada konsumen adalah sebagai berikut:

1. Prospecting

2. Perencanaan pra penjualan

3. Presentasi Penjualan

4. Mengatasi keberatan

5. Prospek

6. Menutup penjualan

III. Evaluasi

Usaha mikro mampu menerapkan manajemen perubahan, pemasaran dengan baik dan dapat meningkatkan daerah pemasarannya serta tertib laporan keuangan..

\section{KESIMPULAN}

$\begin{array}{ccr}\text { Pengabdian } & \text { kepada } & \text { masyarakat } \\ \text { dilakukan pada } & \text { Desa } & \text { Sangkanhurip }\end{array}$
Kecamatan Ketapang Kabupaten Bandung. Usaha mikro yang menjadi perhatian kami adalah produksi kuliner tradisional dawet dan produk turunanya yang terdiri dari dodol moyeg, palupis, ketan goreng dan cilok. Kami memberikan pelatihan pembukuan sederhana kepada UMKM agar dapat membantu memberikan gambaran kondisi keuangan UMKM dan dapat membuat strategi pemasaran dengan menerapkan manajemen perubahan untuk menghasilkan keuntungan yang lebih besar lagi. Penjualan makanan tradisional ini belum memiliki merk dagang dan belum didaftarkan untuk mendapatakan PIRT, serta belum dapat menghitung berapa harga pokok dan harga jual yang semestinya dijual kepada pembeli. Sehingga, peneliti selanjutnya dapat menggunakan topik tersebut untuk melanjutkan bahan pengabdian.

\section{DAFTAR PUSTAKA}

Monografi Desa Bojongkunci, 2015. http://desabojongkunci.blogspot.co.id /2015/06/peta-desa-bojongkunci.html http://www.pikiranrakyat.com/ekonomi/20 10/03/31/110279/opak- sukamanahdiproduksi-secara-turun-temurun.

Ikatan Akuntan Indonesia. (2009). Standar Akuntansi Keuangan Entitas Tanpa Akuntabilitas Publik. Jakarta: Dewan Standar Akuntansi Keungan.

Undang-Undang Nomor 20 Tahun 2008 Tentang Usaha Mikro, Kecil, dan Menengah (UMKM). 